\title{
PREDICTING ENGINEERING FACTORS RELATED TO SOIL AMENDMENTS USING NEURAL NETWORKS
}

\section{D.M. Boulos ${ }^{1}$; M.N. EL Awady ${ }^{2}$;.Tawfic ${ }^{3}$ and M.Z. El Attar ${ }^{4}$}

\section{ABSTRACT}

Artificial Neural Network model is used to predict engineering factors [bulk density, hydraulic conductivity, infiltration rate, soil penetration resistance and available water], under three different soil amendments [Bitumen Emulsion, Polyacrylamide and Organic Manure]. Multilayer feedforward ANN with 11 input and 5 output neurons was trained using a backpropagation learning algorithm. The data needed to train and test the ANN model was obtained from previous literatures. The inputs were soil amendments [Bitumen Emulsion (BE), Polyacrylamide (PAM) and Organic Manure (OM)], soil texture [Sand (S), Silt (Si) and Clay $(C)$ ], engineering factors [Initial bulk density $(I B d)$, Initial hydraulic conductivity (IKa), Initial infiltration rate (IIr), Initial Soil penetration resistance (ISp) and Initial available water (IAW)]. The outputs were final Bd, Ka, Ir, Sp and AW. The result of Artificial Neural Network model showed that the variations between measured and predicted engineering factors were very small. A field experiment was carried out in the Agricultural Experiment Station of the Desert Research Center at Ras Sidr (رأس سدر), South Sinai Governorate. The experiment studied the effect of three soil amendments on some engineering factors, productivity of sorghum yield and water use efficiency. The results showed that the soil amendments improved the engineering factors in general. Optimum values for productivity and water use efficiency were obtained by applying Organic Manure $23128 \mathrm{Mg} / \mathrm{fed}$ and $26.6 \mathrm{~kg} / \mathrm{m}^{3}$ respectively. Least values were obtained by applying Polyacrylamide $15559 \mathrm{Mg} / \mathrm{fed}$ and $13.14 \mathrm{~kg} / \mathrm{m}^{3}$ respectively.

1. Assist. Res., 3. Prof.,Emt.; Soil Phys., Desert Res. Center.

2. Prof.,Emt., 4. Assist. Prof. Agric. Eng.; Fac. of Agric. Ain Shams Univ. 


\section{INTRODUCTION}

NN (Artificial Neural Network) is an algorithmic system an
implemented in either software or hardware. It is a group of
neurons or processing elements and weighted connections. The connections correspond to axons and the weights to synapses in the biological brain. Backpropagation is one of several possible learning rules to adjust the connection weights during learning by example.

On the other hand, it was generally accepted that soil amendments increase the stability of intra-aggregate bonding, thereby alter the soil bulk density, total porosity as well as the configuration of pores and their size distribution, soil penetration resistance, hydraulic conductivity, infiltration rate, moisture characteristics and plant growth.

The objective of this study is to use the ANN model to predict engineering factors related to applying different soil amendments.

\section{REVIEW OF LITERATURE}

Tawfik et al. (1992) studied the effect of various application levels of Bitumen Emulsion (BE) and Polyacrylamide (PAM ) on soil moisture, soil strength and wheat growth with three soils, namely; sandy, calcareous sandy loam and calcareous loamy sand. The results showed that the BE increased the range of available soil moisture than PAM. As to soil strength, the results showed that amendments of the studied soils with BE and PAM increased its strength relative to the control. The same resulted to wheat growth productivity and the advantage of BE.

El Kommos and Noor El-Din (1990) studied the effect of treated soil with Ismailia canal (ترعة الأسماعيلية) spoil (0, 30 and $60 \mathrm{Mg} / \mathrm{f})$ and wheat straw $(0,2.5$ and $5 \mathrm{Mg} / \mathrm{f})$ on wheat and beans production in sandy soil. The data showed that addition of either shaffed wheat straw or canal spoil resulted in a significant increase in the yield of both tested crops, and the yield values increased progressively with the treatments application. Moreover, the combination of both amendments improved considerably the plant growth and crop yield.

El-Hady (1991) applied BE 0.5, 1 and $2 \%$ in a sandy loam highly saline calcareous soil from Mersa Matrouh (مرسى مطروح) the results show improved hydraulic properties of the soil, increased soil aeration, reduced water loss through evaporation and increased preserved moisture in the root zone. 
ANN researchers are seeking an understanding of nature's capabilities for which people can engineer solutions to problems that have not been solved by traditional computing. To do this, the basic unit of ANN, simulates the four basic functions of natural neurons. Fig.(1) shows a fundamental representation of an artificial neuron.

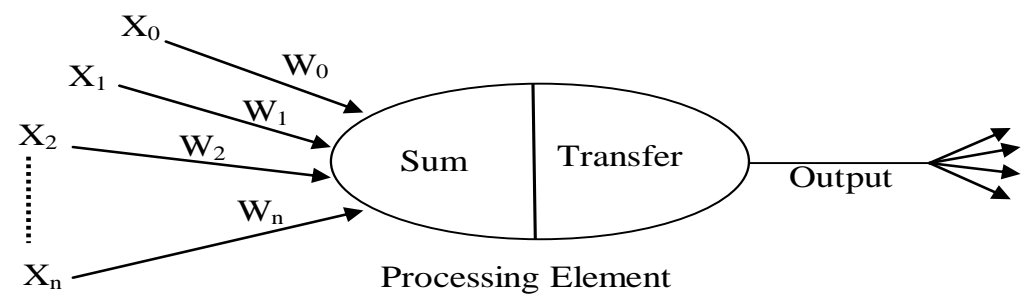

Fig.(1): Basic ANN.

Various inputs to the network are represented by the mathematical symbol, (Xn). Each of these inputs is multiplied by a connection weight. These weights are represented by $(\mathrm{Wn})$. In the simplest case, these products are simply summed, fed through a transfer function to generate a result, and then output. This process lends itself to physical implementation on a large scale in a small package. This electronic implementation is still possible with other network structures which utilize different summing functions as well as different transfer functions . Inputs enter into the processing element from the upper left Fig .(2). The first step is for each of these inputs to be multiplied by a respective weighting factor $(\mathrm{Wn})$.

Summation

Transfer

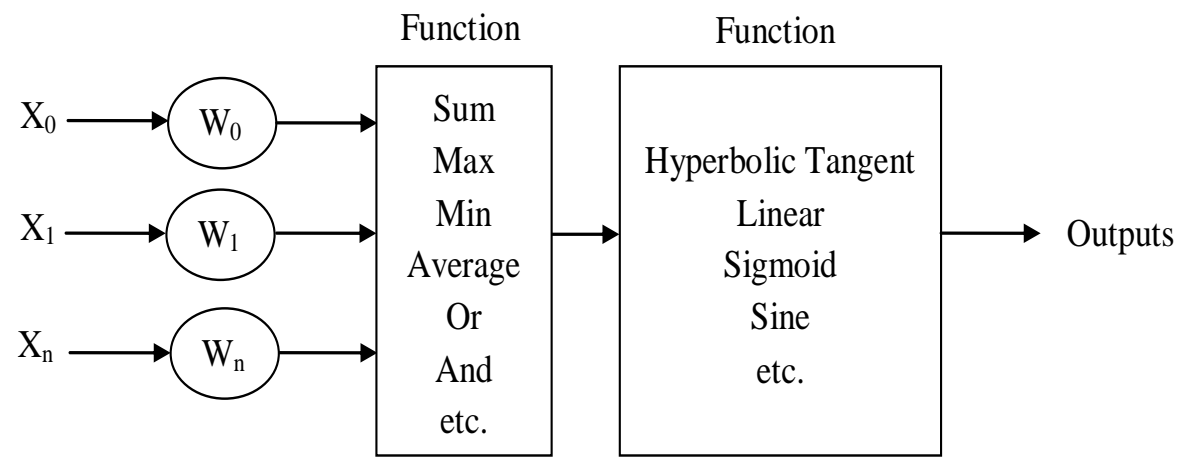

Fig.(2) :Model of processing element. 
Then these modified inputs are fed into the summing function, which usually just sums these products. Yet, many different types of operations can be selected. These operations could produce a number of different values which are then propagated forward; values such as the average, the largest, or the smallest values, etc.

Either way, the output of the summing function is then sent into a transfer function. This function then turns this number into a real output via some algorithm. It is this algorithm that takes the input and turns it into a zero or a one, a minus one or a one, or some other number. The transfer functions that are commonly supported are step, sigmoid, sine, hyperbolic tangent, etc. This transfer function also can scale the output or control its value via thresholds. The result of the transfer function is usually the direct output of the processing element.

Sorour (2006) used ANN model to estimate deterioration of wheat during storage under different conditions. The results showed that an ANN approach estimates dry matter loses and safe storage time of stored wheat under different conditions well compared to measured values.

El Awady et al. (2003) developed an ANN to predict draft, unit draft and energy requirements during plowing process with chisel plow. The developed ANN was used to study the relative importance of variables affecting chisel plows performance. The results showed that correlation coefficients were over 0.90 during testing process and the rated plow width was the major variable affecting draft, unit draft and energy requirements.

El Awady et al. (2004) predicted unit draft of tillage implements using statistical and ANN models. The ANN was a multilayer feedforward network with 11 input and 1 output neurons. The input variables were chisel plow, moldboard plow, disc plow, soil texture index, plowing depth, rated plow width, forward speed, initial soil moisture content, initial soil bulk density, rated tractor power, and the number of plow passes over the soil. The output predicted the unit draft of tillage implement. The standard deviations of the errors were 9.38, 6.57 and $8.45 \mathrm{kN} / \mathrm{m}^{2}$ for moldboard, chisel and disc plows respectively. Also the coefficients of the linear correlation between the measured and predicted values were higher than 0.95 for both the ANN and statistical models. 
Aboukarima (2007) obtained draft data for chisel plows working in different soil conditions, rated plow width and operational parameters with the help of simulation results using ANN. Polynomial draft models from regression analyses were formulated. The independent variables were forward speed, plowing depth, nominal tractor power, rated plow width, soil texture index, initial soil moisture content and initial soil specific weight. The coefficients of determination $\mathrm{R}^{2}$ were higher than 93\%.

Akbarzadeh et al. (2009) due to difficulties in direct measuring of soil erosion by simulated rainfall; used alternative methods consisting of ANN for predicting runoff water and splash of soil particles for each run in soils covered with synthetic geotextiles and bare soils. It was found that the ANN had better accuracy than multivariate regression for prediction of runoff and splash.

\section{MATERIALS AND METHODS}

\section{Experimental design}

The experimental field area of $3037.5 \mathrm{~m}^{2}$ in the Agricultural Experiment Station of the Desert Research Center at Ras Sidr (راس سدر), South Sinai Governorate was divided into three equal main plots, i.e. $1012.5 \mathrm{~m}^{2}(13.5$ $\mathrm{m}$ wide and $75 \mathrm{~m}$ long) for each Fig.(1). These plots represent soil amendment treatments (BE, PAM and OM). Each plot treatment was divided into three sub-treatments according to levels of application. Surge flow irrigation ( 5 min on - 20 min off); 4 surges and inflow rate $0.5 \mathrm{~L} / \mathrm{s}$ was applied similar to Boulos (2006). Each treatment contained four furrows, the middle two were used as replicates and the others were used as buffer furrows.

\section{The ANN model}

In this study, a backpropagation ANN with one hidden layer was used. This type of ANN is a nonlinear data transformation structure consisting of input and output nodes connected to a number of hidden nodes by adaptable coefficients. The number of input and output nodes corresponds to the number of input and output variables. The number of hidden nodes depends on the complexity of the underlying problem and is determined empirically by calibrating ANN with different numbers of 
hidden nodes. Both the hidden and output nodes contain sigmoid transfer function that provides the ANN with nonlinear capabilities.

Gated pipe

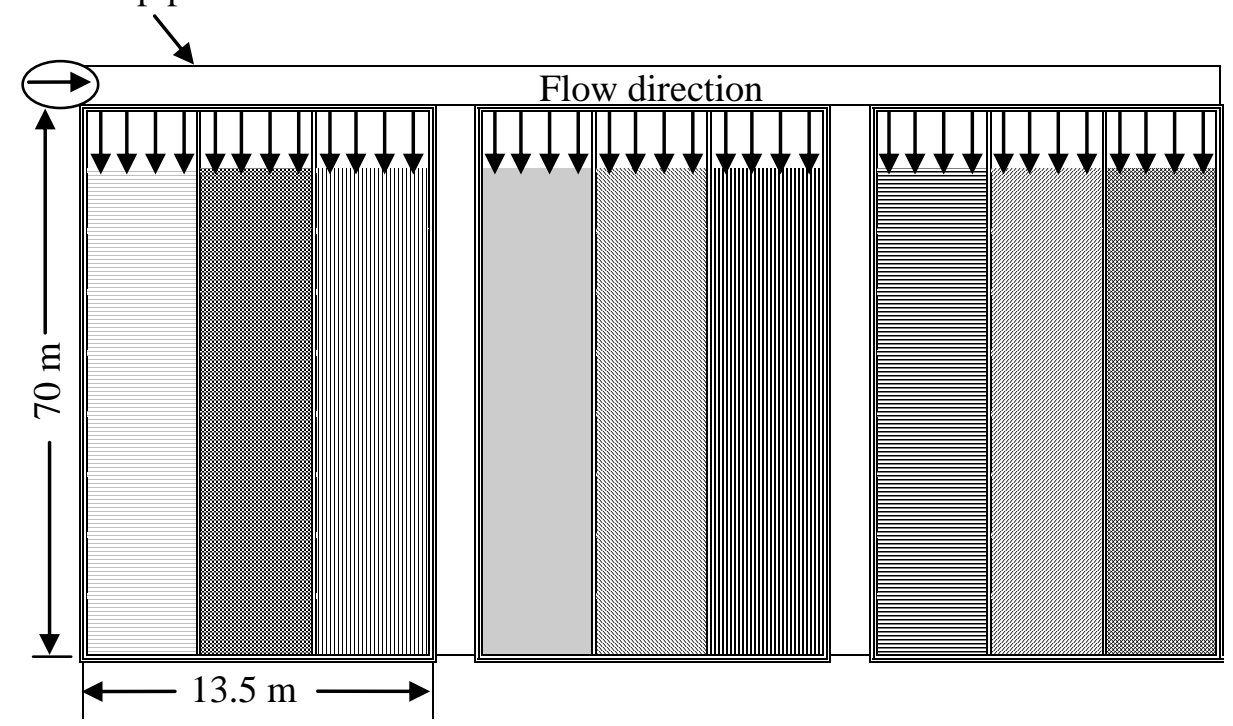

\begin{tabular}{|c|c|c|}
\hline BE $0.5 \%$ & PAM $0.05 \%$ & $\mathrm{OM} 10 \mathrm{Mg} / \mathrm{fed}$. \\
\hline BE $1 \%$ & PAM $0.1 \%$ & OM $20 \mathrm{Mg} / \mathrm{fed}$. \\
\hline BE $1.5 \%$ & PAM $0.15 \%$ & OM $30 \mathrm{Mg} / \mathrm{fed}$. \\
\hline Pump & Gate & \\
\hline
\end{tabular}

Fig.(1): Layout of field experiment.

The optimum solution was decided upon minimizing the difference between the ANN and the desired outputs. The Root Mean Square Error (RMSE) and correlation coefficient $\left(\mathrm{R}^{2}\right)$ were used for the determination of ANN performance.

RMSE $=\sqrt{\frac{1}{n} \sum_{i=1}^{n}\left(x_{i}-y_{i}\right)^{2}}$

where:

$\mathrm{n}=$ number of data points during testing process,

$\mathrm{x}_{\mathrm{i}} \quad=$ observed soil physical property, and

$\mathrm{y}_{\mathrm{i}} \quad=$ predicted soil physical property. 


\section{Soil physical properties determinations.}

\section{Soil bulk density.}

$$
\mathrm{Bd}=\mathrm{M} / \mathrm{V}
$$

Where:

$\mathrm{Bd}=$ The bulk density in $\left(\mathrm{g} / \mathrm{cm}^{3}\right)$

$\mathrm{M}=$ The mass of soil in $(\mathrm{g})$

$\mathrm{V}=$ Soil volume in $\left(\mathrm{cm}^{3}\right)$

\section{Soil penetration resistance.}

The penetration resistance was determined for the soil profile before and after applying treatments using a Japanese penetrometer.

3. Infiltration rate.

$\mathrm{D}=\mathrm{St}^{0.5}+\mathrm{At}$

$\mathrm{I}=\mathrm{St}^{-0.5}+\mathrm{A}$

where:

$\mathrm{D}=$ cumulative infiltration depth $(\mathrm{mm})$

$\mathrm{I}=$ infiltration rate $(\mathrm{mm} / \mathrm{h})$

$\mathrm{t}=$ time $(\mathrm{h})$

A and $\mathrm{S}=$ constants.

\section{Hydraulic conductivity.}

$$
k=\frac{Q \Delta L}{t A \Delta H}
$$

where: $k=$ Hydraulic conductivity in $\mathrm{cm} / \mathrm{h}$

$Q=$ Volume of water in $\mathrm{cm} 3$

$\Delta L=$ Soil interval in $\mathrm{cm}$

$t=$ Time in hour

$A=$ Area of the core in $\mathrm{cm} 2$

$\Delta H=$ Hydraulic head in $\mathrm{cm}$

\section{Soil moisture.}

Retained soil moisture at 0.33 bar and 15 bar by using pressure cooker and pressure membrane.

\section{Water - Use Efficiency.}

$\mathrm{WUE}=\mathrm{Y} / \mathrm{IR}$

Where: 
WUE $=$ water - use efficiency in $\left(\mathrm{kg} / \mathrm{m}^{3}\right)$,

$\mathrm{Y}=$ total crop yield in $(\mathrm{kg} / \mathrm{fed})$ and

$\mathrm{IR}=$ total amount of water use in the field in $\left(\mathrm{m}^{3} / \mathrm{fed}\right)$.

\section{RESULTS AND DISCUSSION}

\section{Effect of soil amendments on engineering factors.}

The data in Fig.(2) indicate that applying soil amendments decreased the soil bulk density relative to the control. The data reveal a high decrease in soil bulk density under OM than the other soil amendments (BE \& PAM).

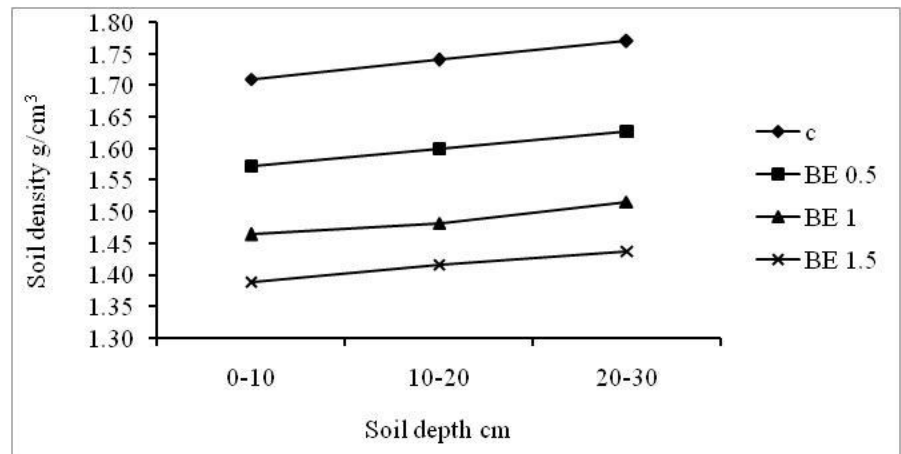

Fig.(2): Effect of Bitumen Emulsion rate on soil bulk density.

Under PAM the water movement (infiltration rate \& hydraulic conductivity) in the soil has slight decrease, Fig.(3), but under OM the soil highly decreased.

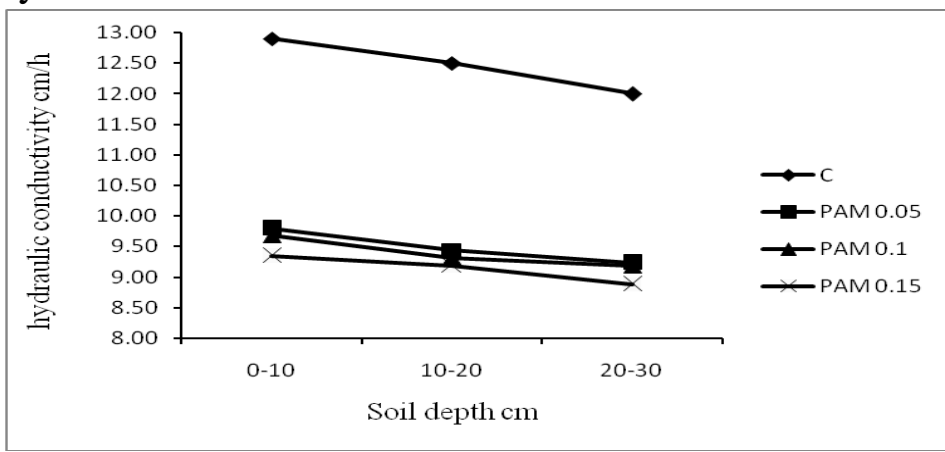

Fig.(3): Effect of Polyacrylamide on hydraulic conductivity.

$\mathrm{OM}$ increases soil penetration resistance and BE, PAM have the same direction. Treating the soil with OM caused sharp increase in available water Fig.(4). 


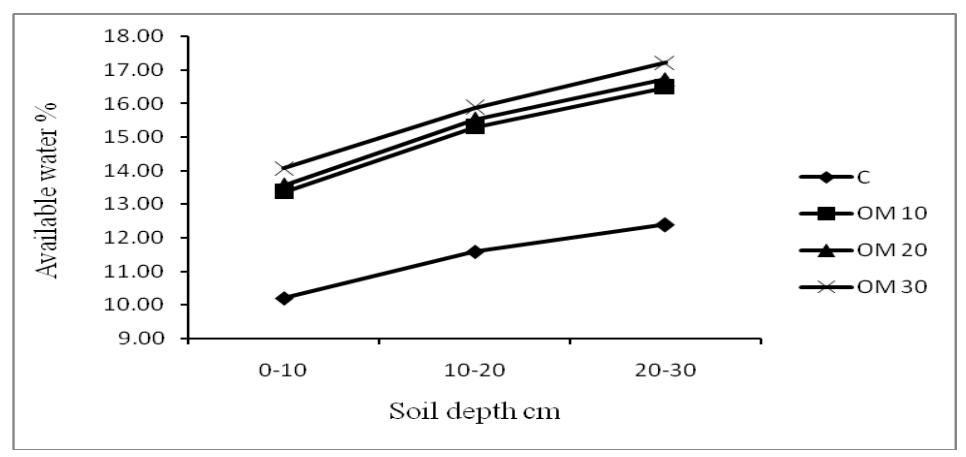

Fig.(4): Effect of Organic Manure on available water.

Sorghum productivity increased under all soil amendments. OM gave high productivity, Fig.(5). The good profit gain from OM is 20 ton/fed.

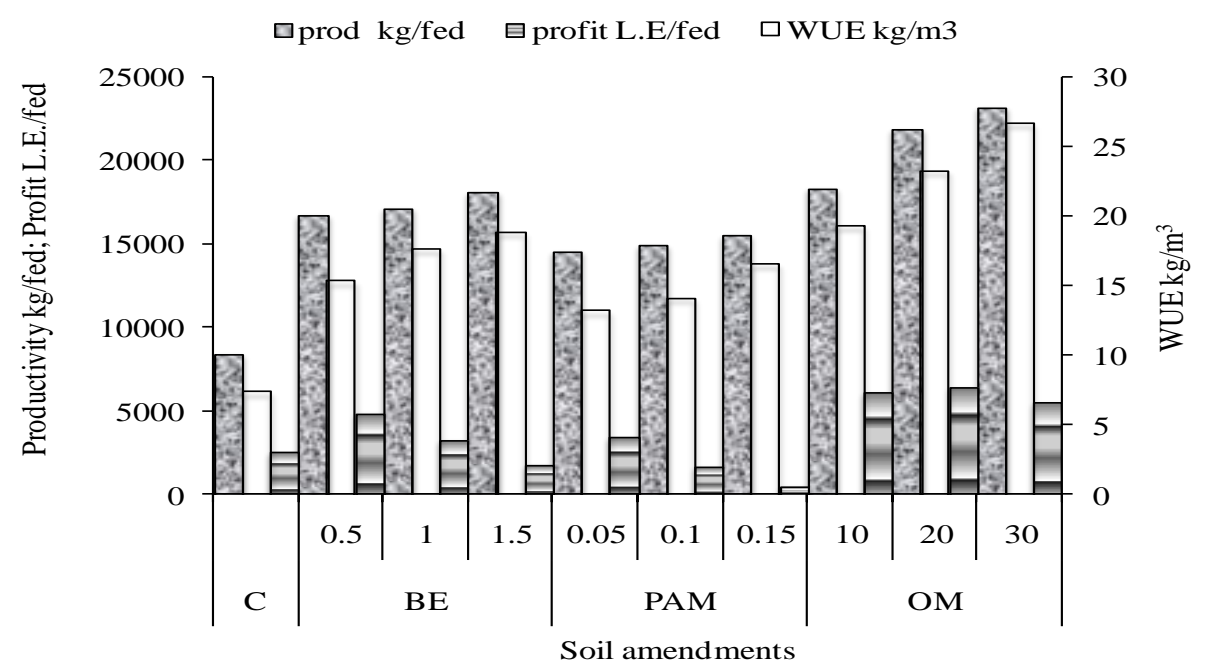

Fig.(5): Effect of different soil amendments on sorghum productivity and profit.

The effects of soil amendments (BE, PAM and OM) on engineering factors (Bd, Ka, Ir, Sp and AW) were unstable. They depend on soil texture (sand, silt and clay). So we have various alternatives of soil amendments, engineering factors and soil textures.

The data from literature were separated into two groups. $75 \%$ of the data were set for training, Table (1) and about $25 \%$ for testing. Several ANN models were trained with various design parameters including number of hidden layers and number of nodes in each hidden layer. The selection of 
the optimum model was based on minimizing the difference between the ANN predicted and expected outputs. The best model consisted of one hidden layer with 15 nodes, Fig.(6).

Table (1): Data from literatures used in training ANN model.

\begin{tabular}{|c|c|c|c|c|c|c|c|c|c|c|}
\hline \multicolumn{3}{|c|}{ Soil amendments } & \multicolumn{3}{|c|}{ Soil texture } & \multicolumn{5}{|c|}{ Initial engineering factors } \\
\hline $\mathrm{BE}$ & PAM & $\mathrm{OM}$ & Sand & Silt & Clay & $\mathrm{IBd}$ & $\mathrm{IKa}$ & IIr & ISp & IAW \\
\hline 0.5 & 0 & 0 & 95.96 & 3.52 & 0.52 & 1.85 & 15.2 & 18.3 & 10 & 5.1 \\
\hline 0.5 & 0 & 0 & 92.32 & 6.4 & 1.28 & 1.82 & 15.3 & 18.6 & 10.8 & 4.5 \\
\hline 0.5 & 0 & 0 & 95.47 & 4.13 & 0.4 & 1.83 & 15.6 & 18.2 & 10.2 & 4.6 \\
\hline 0.5 & 0 & 0 & 94.96 & 4.69 & 0.35 & 1.86 & 15.4 & 18.4 & 10.1 & 5.2 \\
\hline 0.5 & 0 & 0 & 90.41 & 8.6 & 0.99 & 1.81 & 15.2 & 18.3 & 10.5 & 5.1 \\
\hline 0.5 & 0 & 0 & 96.47 & 2.61 & 0.92 & 1.84 & 15.1 & 18 & 10.3 & 4.3 \\
\hline 0.5 & 0 & 0 & 95.75 & 3.4 & 0.85 & 1.83 & 15 & 18.4 & 10.2 & 4.2 \\
\hline 0.5 & 0 & 0 & 97.08 & 1.36 & 1.56 & 1.86 & 15.3 & 18.5 & 10 & 5.2 \\
\hline 0.5 & 0 & 0 & 98.15 & 1.58 & 0.27 & 1.85 & 15.2 & 18.1 & 10.5 & 5.1 \\
\hline 0.5 & 0 & 0 & 97.05 & 1.64 & 1.31 & 1.82 & 15.4 & 18.2 & 10.2 & 5.2 \\
\hline 1 & 0 & 0 & 98.68 & 0.53 & 0.79 & 1.85 & 15.2 & 18.3 & 10 & 5.1 \\
\hline 1 & 0 & 0 & 95.5 & 3 & 1.5 & 1.82 & 15.3 & 18.6 & 10.8 & 4.5 \\
\hline 1 & 0 & 0 & 91 & 3.2 & 5.8 & 1.83 & 15.6 & 18.2 & 10.2 & 4.6 \\
\hline 1 & 0 & 0 & 98.47 & 0.61 & 0.92 & 1.86 & 15.4 & 18.4 & 10.1 & 5.2 \\
\hline 1 & 0 & 0 & 99 & 0.05 & 0.95 & 1.81 & 15.2 & 18.3 & 10.5 & 5.1 \\
\hline 1 & 0 & 0 & 96.77 & 1.06 & 2.17 & 1.84 & 15.1 & 18 & 10.3 & 4.3 \\
\hline 1 & 0 & 0 & 96.21 & 1.63 & 2.16 & 1.83 & 15 & 18.4 & 10.2 & 4.2 \\
\hline 1 & 0 & 0 & 93.8 & 3.4 & 2.8 & 1.86 & 15.3 & 18.5 & 10 & 5.2 \\
\hline 1 & 0 & 0 & 91.97 & 5.93 & 2.1 & 1.85 & 15.2 & 18.1 & 10.5 & 5.1 \\
\hline 1 & 0 & 0 & 91.25 & 1.05 & 7.69 & 1.82 & 15.4 & 18.2 & 10.2 & 5.2 \\
\hline 1.5 & 0 & 0 & 98.68 & 0.53 & 0.79 & 1.85 & 15.2 & 18.3 & 10 & 5.1 \\
\hline 1.5 & 0 & 0 & 95.5 & 3 & 1.5 & 1.82 & 15.3 & 18.6 & 10.8 & 4.5 \\
\hline 1.5 & 0 & 0 & 91 & 3.2 & 5.8 & 1.83 & 15.6 & 18.2 & 10.2 & 4.6 \\
\hline 1.5 & 0 & 0 & 98.47 & 0.61 & 0.92 & 1.86 & 15.4 & 18.4 & 10.1 & 5.2 \\
\hline 1.5 & 0 & 0 & 99 & 0.05 & 0.95 & 1.81 & 15.2 & 18.3 & 10.5 & 5.1 \\
\hline 1.5 & 0 & 0 & 96.77 & 1.06 & 2.17 & 1.84 & 15.1 & 18 & 10.3 & 4.3 \\
\hline 1.5 & 0 & 0 & 96.21 & 1.63 & 2.16 & 1.83 & 15 & 18.4 & 10.2 & 4.2 \\
\hline 1.5 & 0 & 0 & 93.8 & 3.4 & 2.8 & 1.86 & 15.3 & 18.5 & 10 & 5.2 \\
\hline 1.5 & 0 & 0 & 91.97 & 5.93 & 2.1 & 1.85 & 15.2 & 18.1 & 10.5 & 5.1 \\
\hline 1.5 & 0 & 0 & 91.25 & 1.05 & 7.69 & 1.82 & 15.4 & 18.2 & 10.2 & 5.2 \\
\hline 0 & 0.05 & 0 & 98.68 & 0.53 & 0.79 & 1.85 & 15.2 & 18.3 & 10 & 5.1 \\
\hline 0 & 0.05 & 0 & 95.5 & 3 & 1.5 & 1.82 & 15.3 & 18.6 & 10.8 & 4.5 \\
\hline 0 & 0.05 & 0 & 91 & 3.2 & 5.8 & 1.83 & 15.6 & 18.2 & 10.2 & 4.6 \\
\hline 0 & 0.05 & 0 & 98.47 & 0.61 & 0.92 & 1.86 & 15.4 & 18.4 & 10.1 & 5.2 \\
\hline 0 & 0.05 & 0 & 99 & 0.05 & 0.95 & 1.81 & 15.2 & 18.3 & 10.5 & 5.1 \\
\hline 0 & 0.05 & 0 & 96.77 & 1.06 & 2.17 & 1.84 & 15.1 & 18 & 10.3 & 4.3 \\
\hline 0 & 0.05 & 0 & 96.21 & 1.63 & 2.16 & 1.83 & 15 & 18.4 & 10.2 & 4.2 \\
\hline 0 & 0.05 & 0 & 93.8 & 3.4 & 2.8 & 1.86 & 15.3 & 18.5 & 10 & 5.2 \\
\hline 0 & 0.05 & 0 & 91.97 & 5.93 & 2.1 & 1.85 & 15.2 & 18.1 & 10.5 & 5.1 \\
\hline 0 & 0.05 & 0 & 91.25 & 1.05 & 7.69 & 1.82 & 15.4 & 18.2 & 10.2 & 5.2 \\
\hline 0 & 0.1 & 0 & 98.68 & 0.53 & 0.79 & 1.85 & 15.2 & 18.3 & 10 & 5.1 \\
\hline 0 & 0.1 & 0 & 95.5 & 3 & 1.5 & 1.82 & 15.3 & 18.6 & 10.8 & 4.5 \\
\hline 0 & 0.1 & 0 & 91 & 3.2 & 5.8 & 1.83 & 15.6 & 18.2 & 10.2 & 4.6 \\
\hline 0 & 0.1 & 0 & 98.47 & 0.61 & 0.92 & 1.86 & 15.4 & 18.4 & 10.1 & 5.2 \\
\hline 0 & 0.1 & 0 & 99 & 0.05 & 0.95 & 1.81 & 15.2 & 18.3 & 10.5 & 5.1 \\
\hline 0 & 0.1 & 0 & 96.77 & 1.06 & 2.17 & 1.84 & 15.1 & 18 & 10.3 & 4.3 \\
\hline 0 & 0.1 & 0 & 96.21 & 1.63 & 2.16 & 1.83 & 15 & 18.4 & 10.2 & 4.2 \\
\hline 0 & 0.1 & 0 & 93.8 & 3.4 & 2.8 & 1.86 & 15.3 & 18.5 & 10 & 5.2 \\
\hline 0 & 0.1 & 0 & 91.97 & 5.93 & 2.1 & 1.85 & 15.2 & 18.1 & 10.5 & 5.1 \\
\hline 0 & 0.1 & 0 & 91.25 & 1.05 & 7.69 & 1.82 & 15.4 & 18.2 & 10.2 & 5.2 \\
\hline
\end{tabular}




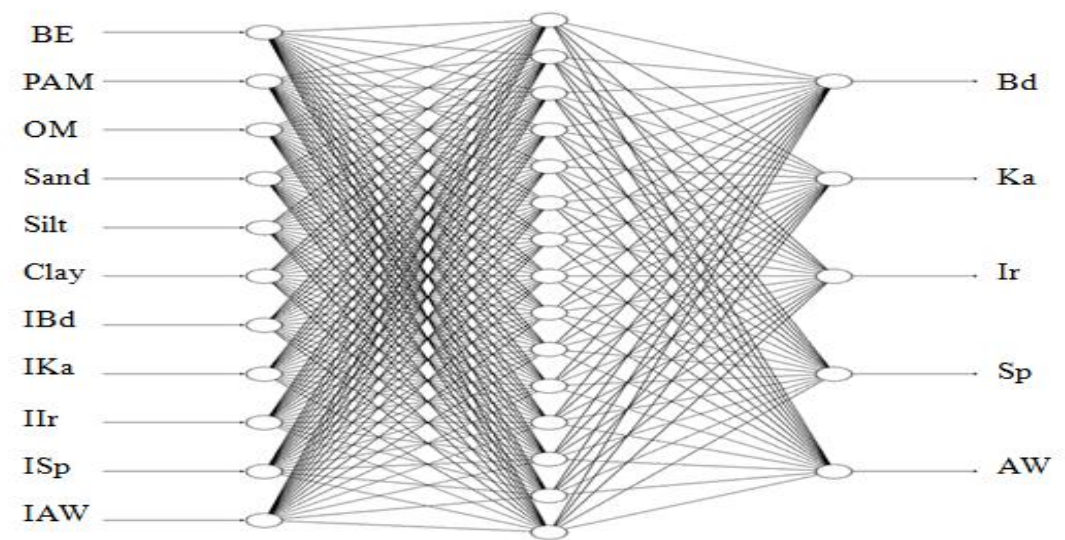

Fig.(6): The architecture of the ANN model.

The inputs were Bitumen Emulsion (BE), Polyacrylamide (PAM), Organic Manure (OM), sand, silt, clay, Initial bulk density (IBd), Initial hydraulic conductivity (IKa), Initial infiltration rate (IIr), Initial soil penetration resistance (ISp) and Initial available water (IAW). The outputs were bulk density (Bd), hydraulic conductivity (Ka), infiltration rate (Ir), soil penetration resistance (Sp) and available water (AW). The RMSE decreased with increasing of learning iterations for 5 outputs. The best results were achieved at 100,000 training runs with RMSE at 0.0087 Fig.(7).

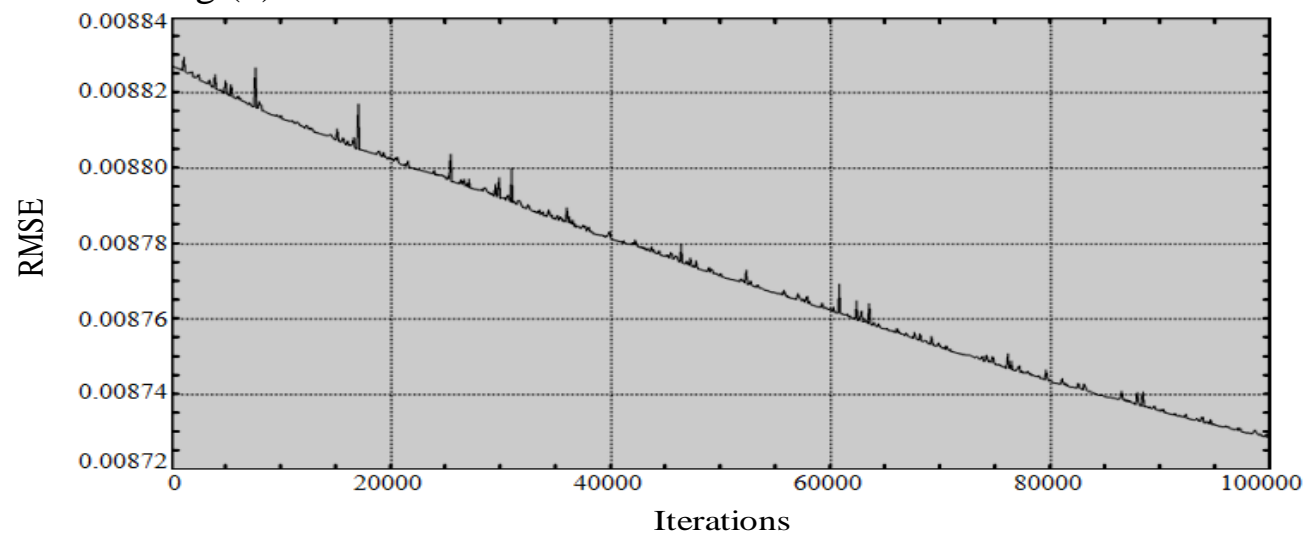

Fig.(7): RMSE for iterations finding out effect of soil amendments and engineering factors.

After the training process, the ANN was tested with new values, and the predicted engineering factors $\mathrm{Bd}, \mathrm{Ka}, \mathrm{Ir}, \mathrm{Sp}$ and $\mathrm{AW}$ were compared with 
observed values, Table (2) and Fig.(8). There was a small difference between predicted and observed values, so that the correlation coefficient was equal 0.999 .

Table (2): Observed and predicted engineering factors from testing ANN model.
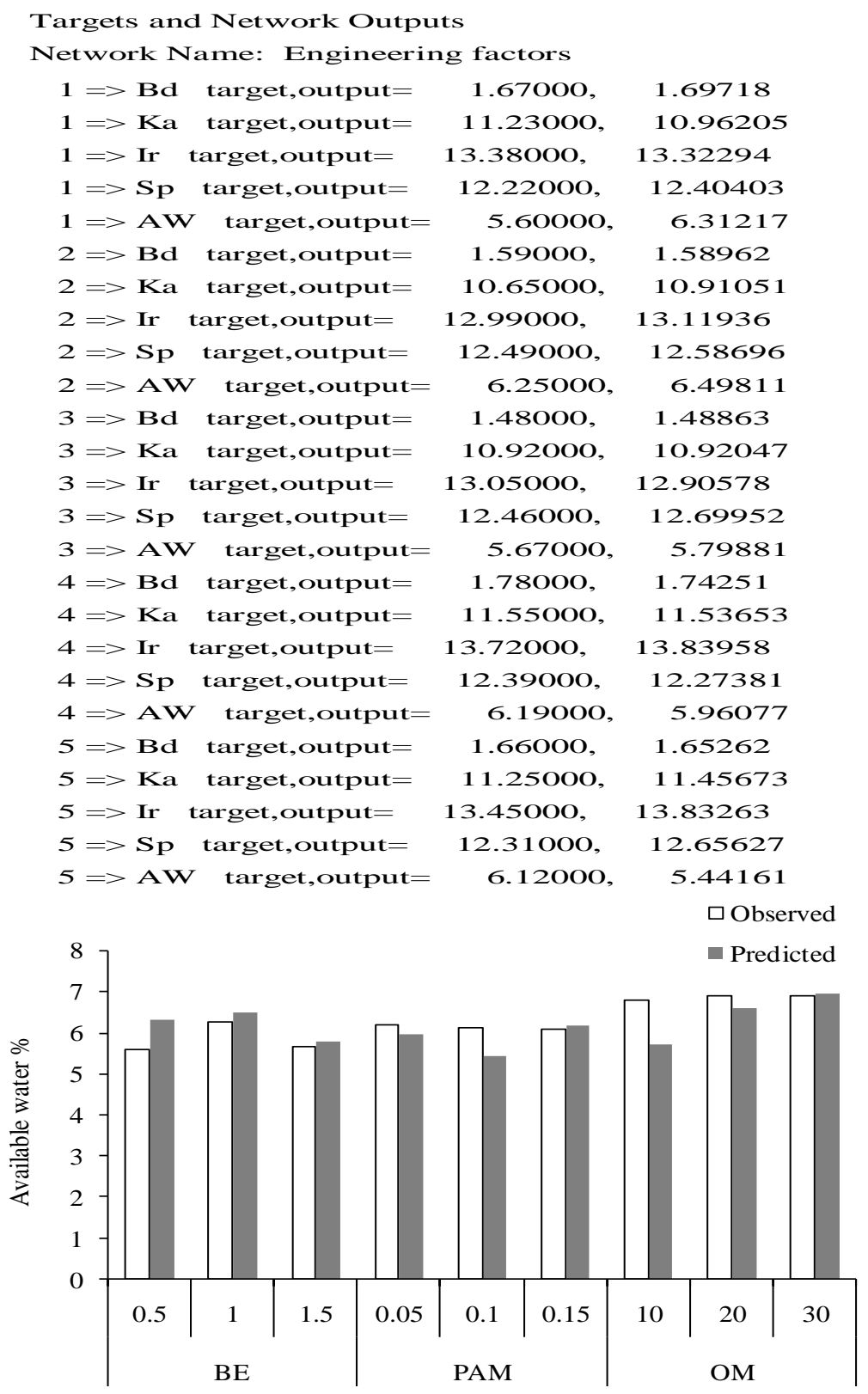

Fig.(8): Available water of ANN predicted and observed values from different soil amendments. 


\section{CONCLUSION}

The Artificial Neural Network model is used for prediction of engineering factors for soil physical properties with applying different soil amendments. Multilayer feedforward ANN succeeded with 11 inputs, one hidden layer with 15 nodes and 5 outputs. The inputs were soil amendments [Bitumen Emulsion (BE), Polyacrylamide (PAM) and Organic Manure $(\mathrm{OM})$ ], soil texture [Sand (S), Silt (Si) and Clay (C)], engineering factors [Initial bulk density (IBd), Initial hydraulic conductivity (IKa), Initial infiltration rate (IIr), Initial Soil penetration resistance (ISp) and Initial available water (IAW)]. The outputs were final $\mathrm{Bd}, \mathrm{Ka}, \mathrm{Ir}, \mathrm{Sp}$ and $\mathrm{AW}$. The best result was achieved at 100000 training runs. Artificial Neural Network model proved to be one of the good tools for prediction. The correlation coefficient between predicted and observed values was at 0.999 for new values used for testing the accuracy of the predicting system.

In general soil amendments in sandy, loamy sand and sandy loam soils showed a positive effect on properties factors such as soil penetration resistance; available water and sorghum productivity, and have negative effect on bulk density, hydraulic conductivity and infiltration rate. The high increase in productivity was under organic manure 30 ton/fed. The bitumen emulsion and polyacrylamide have good effect on productivity compared to control, but both are not like organic manure in increased percentage. On the other hand, the profit under both of them is much less than organic manure, because they are expensive.

\section{REFERENCES ${ }^{*}$}

Aboukarima, A.M.(2007). Draft models of chisel plow based on simulation using artificial neural networks. Misr J. Ag. Eng., 24(1): 42-61.

Akbarzadeh A.; R.T. Mehrjardi; H. Rouhipour; M. Gorji and H.G. Refahi (2009). Estimating of soil erosion covered with rolled erosion control systems using rainfall simulator (Neuro-fuzzy and Artificial Neural Network Approaches). J. of Ap. Sci. Res., 5(5): 505-514.

$\overline{\text { * Arabic definition article "El" was waived when arranging author names alphabetically. }}$ 
El Awady, M.N.; A.G. El-Kabany; M.H. Kabeel and A.M. Aboukarima (2003). Relative importance of variables affecting chisel plow performance using neural networks. The $11^{\text {th }}$ Conf. of Misr Soc. of Ag. Eng.: 395-407.

El Awady, M.N.; A.G. El-Kabany; M.H. Kabeel and A.M. Aboukarima (2004). Predicting unit draft of tillage implements using statistical models and neural networks. The $12^{\text {th }}$ Conf. of Misr Soc. of Ag. Eng.: 139-249.

Boulos, D.M. (2006). A study on some physical factors affecting improved irrigation of desertic soil in Ras Sidr. M. Sc. Th., Fac. of Agric., Ain Shams Univ., Egypt: 30-32.

El Kommos, F. and Y. Noor El-Din (1990). The effect of irrigation frequency under varying soil amendments application on wheat and broad beans production in sandy soils. Eg. J. Soil Sci., 30(3): 403-414.

Sorour, H.M. (2006). Prediction of wheat deterioration during storage period using artificial neural network. Misr J. Ag. Eng., 23(3): 637-657.

Tawfik, A.; S.Y. Metwally; M.A. Afifi and M.A. El-Toni (1992). Effect of soil conditioners on availability of soil moisture, soil strength and plant growth. Eg. J. Soil. Sci., 32(2): 181-195.

$$
\text { الملخص العربى الأنسي }
$$
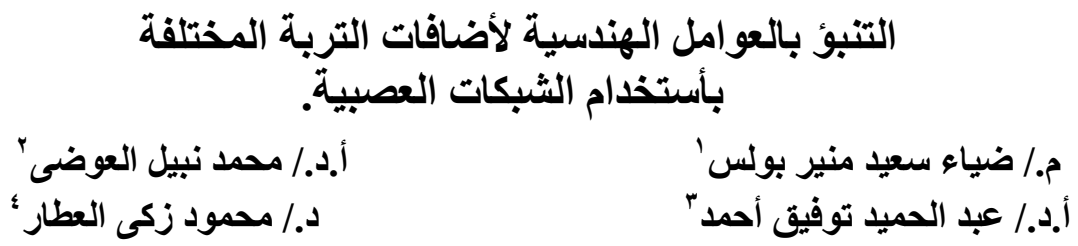

الهـدف مـن هذه الدر اسـة استخدام الثبكات العصبية للتنبؤ بالعو امـل الهندسبة نتيجـة لاسـتخدام

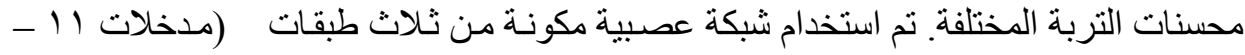

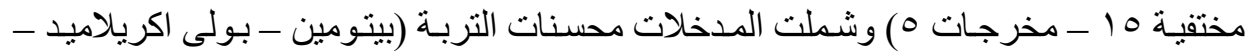

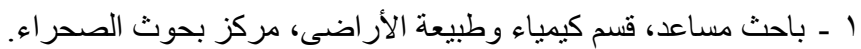

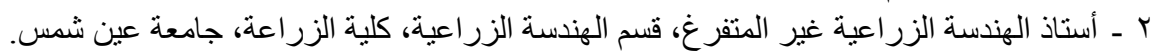

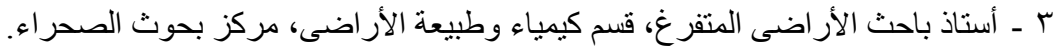

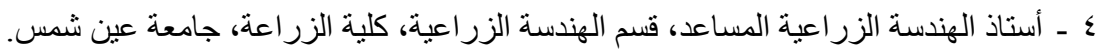


المادة العضوية),

قو ام التربة (رمل - سلت - طين), الكثافة الظاهرية الابتدائية, التوصيل الهيدروليكى الابتدائى,

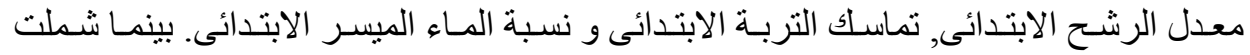
المخرجات الكثافة الظاهرية, التوصيل الهيدروليكى, معدل الرشّح, تماسـك التربـة و نسبة المـاء الميسر ـ و لانثناء وتدريب نموذج الثبكات العصبية فقد تم استخدام بيانات در اسـات سـابقة وكانت

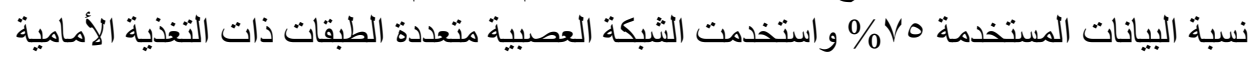
وطريقة التعليم الخلفية ذات التعليم الموجه. وتم اختبار الشبكة ببيانـات لم تشـاهدها اثتاء مرحلة التعلم وبيانات تجربة حقلية. و أظهرت النتائج ان قيم معمل الارتباط 999 9 , . و الجذر التربيعى لمربع الخطأ AV . . . , . ما بين البيانات المسجلة و البيانات المتوقعة. أجريت تجربة حقلية بمحطة بحوث رأس سدر التابعة لمركز بحوث الصحر اء بمحافظلة جنوب المبات

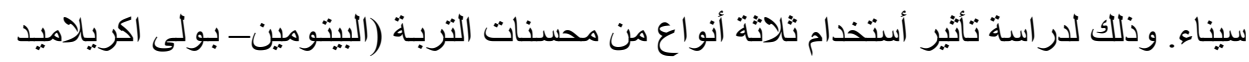

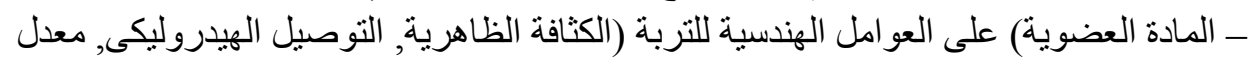
الرشح, تماسك التربة و نسبة الماء الميسر) و انتاجية محصول السورجم وكفاءة أستخدام المياه.

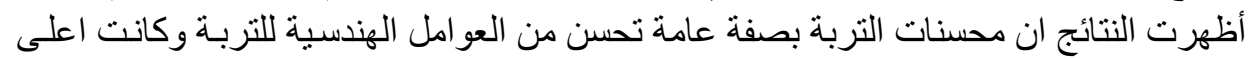
قيم باستخدام المادة العضوية و اقل قيم باستخدام بولى اكريلاميد. 